\title{
STRUCTURAL ANALYSIS OF EXISTING ROAD NETWORKS OF COOCH BEHAR DISTRICT, WEST BENGAL, INDIA: A TRANSPORT GEOGRAPHICAL APPRAISAL \\ Sarkar, D. \\ http://dx.doi.org/10.4314/ejesm.v6i1.9
}

Received 20th September 2012; accepted 15th January 2013

\begin{abstract}
Road has been described as the life-blood of human civilisation. Social interaction and economic prosperity in space have been shaped by the road networks both at intra and inter regional levels. Consequently, it is regarded as one of the most important indices of economic, social and commercial progress of any region. The study area, Cooch Behar District of West Bengal, India ranked 11 out of 19 districts of West Bengal in development indices in spite of its immense historical background. The district does not have any remarkable industrial establishments with the population engaged in subsistence agriculture marked by low yield and productivity. An attempt has been made through the present study to explore the existing pattern and spatial variations of road networks of the study area with the help of structural measures of transportation network. The study reveals that blocks of Cooch Behar district had minimum road density and most of the blocks are characterised by minimum efficiency of road network in terms of connectivity. The efficiency of road network is very low and higher spatial imbalance.
\end{abstract}

Keywords: Spatial variation, road network, efficiency, connectivity, accessibility

\section{Introduction}

Transportation, the movement and exchange of people, goods and services is an obligatory feature of modern life (Umoren et al., 2009) because of its multi-dimensional functions and importance keeping relations and making integrations among every aspect of a society ranging from an individual to a nation. Road that act as key for transportation of people and materials from one place to another have spread like veins and arteries throughout the country and brought substantial development (Badigar and Badigar, 2003). The improvement of transportation through road networks in between any two points leads to increasing regional specialisation reducing the transport costs. Agglomeration economies at not only the large cities but also in rural areas accelerate their growth, expand the markets and increase the dominance of transportation system. The impact of technological change in transport sector since the late $19^{\text {th }}$ century has been as theatrical as in every sphere of life (Simon, 1996). While rebuilding any region or nation or country, roads always play a dynamic part. In essence, transport network is considered as a set of interconnected route linking with numerous destinations within and the outside the region and provides a pace for movement of people and commodities. Practically, it performs manifold functions for the regional development reducing the spatial disparities and it brings equilibrium among societal, economic, political phenomena through the proper utilization of resources. Transportation is not only a resource factor rather; it is a catalyst for the true development of various resource characters. No other transportation system is able to provide such a comprehensive door to door services nor any other mode have such extensive route network. 'Transportation and Spatial Structure' dealt with some characteristics features of the processes in which the transport networks are evolved (Taaffe and Gauthier, 1973). These features play vital role in the development of a region. In the district Cooch Behar of West Bengal, where other means of transport are yet to be developed, a well planned programme of the study of road network for its role in the development processes is urgently needed (Gautam, 1992).

The main objectives of the study are;

1. To provide an idea about the existing road network of the district.

2. To find out the overall status of development of road network of the study area.

3. To find out the spatial variation of road network development of the study area.

4. To suggest some relevant strategies for the policy makers. 


\section{Description of Study Area}

Cooch Behar is located in between $26^{\circ} 32^{\prime} 46^{\prime \prime} \mathrm{N}$ to $25^{\circ} 57^{\prime} 66^{\prime \prime} \mathrm{N}$ latitude and $89^{\circ} 52^{\prime} \mathrm{E}$ to $88^{\circ} 45^{\prime} 02^{\prime \prime} \mathrm{E}$ longitude. The district is surrounded by Jalpaiguri District in north to west, Bangladesh in south, Assam in east. The total geographical area is $3386 \mathrm{Km}^{2}$ and the total population of the district is 28, 22, 780 (Census Report, 2011) with the population density of 833 per $\mathrm{km}^{2}$. The district is a flat region with a slight south eastern slope along which many rivers of the district flow. Most of the high lands areas are found in the Sitalkhuchi region and most of the low laying areas are found in Dinhata region. The district is situated near the eastern Himalayan foothills, after rains in the catchment of each river generally attain strong current and flood in the adjacent areas.

The soil is formed by alluvial deposits and acidic in nature. The district of Cooch Behar has a moderate type of climate characterised by heavy rainfall during the monsoon in the month of June to September. The average annual rainfall is 3201 $\mathrm{mm}$. The district does not have high temperature at any time of the year. The summer is from April to May with April being the hottest month with mean daily maximum temperature of $32.5^{\circ} \mathrm{C}$ and mean daily minimum of $20.2^{\circ} \mathrm{C}$. The winter season lasts from late November to February, with January being the coldest month with temperature ranging from $10.4^{\circ} \mathrm{C}$ to $24.1^{\circ} \mathrm{C}$. The recorded minimum and maximum temperature is $3.9^{\circ} \mathrm{C}$ and $39.9^{\circ} \mathrm{C}$ respectively.

\section{Existing Road Networks of the Study Area}

After independence, the roads networks of the district have been extended a large. In 2008, the district had total $1714.85 \mathrm{~km}$ roads. Roads of the district have been maintained by different sectors of the Government like Public Works Department, Zilla Parisad, Gram Panchayet and Panchayet Samity and PMGSY. The total amount of road maintained by Public Works Department is 808 $\mathrm{Km}$. Out of which $793 \mathrm{Km}$. is surfaced road network and only $15 \mathrm{Km}$ is un-surfaced road. On the other hand $109.35 \mathrm{Km}$ surfaced and $240.5 \mathrm{Km}$. un-surfaced road networks are maintained by Cooch Behar Zilla Parisad. Gram Panchayet and Panchayet Samity maintain $263.25 \mathrm{Km}$. surfaced road networks, while PMGSY bears the responsibility of $293.75 \mathrm{Km}$. surfaced road networks (Table 2). The roads of the study area can be classified in four categories i.e. National High way, State High way, District High way, Rural Roads.

Important roads of the study area are the following:

1. The Emigration Road West

This road has joined the town of Cooch Behar with the sub-divisional town of Mathabhanga and crossing the Tista below Mekhligunj passes west up to Haldibari. A brunch of it goes north-west to Jalpaiguri via Changrabanda.

2. The Emigration Road East

This road connecting Cooch Behar with Dhubri in the District of Goalpara, passing by the north of Balarampur, and has crossed the Sankosh below Kherbari in Ghurla.

3. The Buxa Road

This road has connected Cooch Behar with the Buxa in the Western Duars via Alipurduar.

\section{The Lawkuthi Road}

It has passed through the north-west of the district and connected the town of Cooch Behar with Fulbari and the Buxigunj and Mahishkhuchi Bunders, and then extended up to Haldibari on the Sankos in the Western Duars.

5. The Rangpur Road

This road has brunched out from Emigration Road from a point of three miles east of Cooch Behar, and extended towards Gitaldaha through Dinhata.

6. The Goshanimari and Sitai Road

This road has joined the town of Cooch Behar with Goshanimari and Sitai. In addition, there are a large number of cross roads for transportation between different places within the district. 


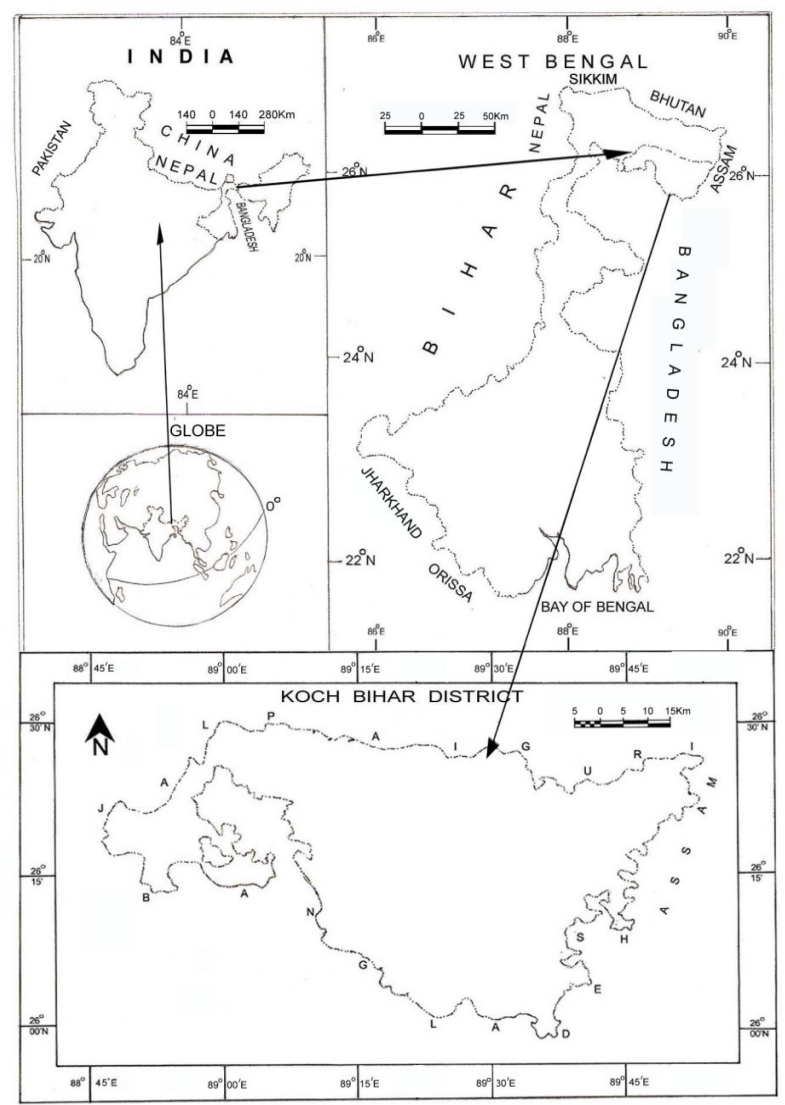

Figure 1 Location Map of Cooch Behar

Table 2 Existing Roads Maintained by Different Sectors of the Government

\begin{tabular}{|c|c|c|c|c|c|c|c|c|c|}
\hline \multirow[t]{2}{*}{ Blocks } & \multicolumn{2}{|l|}{ P.W.D } & \multicolumn{2}{|c|}{ Zilla Parisad } & \multicolumn{2}{|c|}{ GP\& PS } & \multicolumn{2}{|c|}{ PMGSY } & \multirow[t]{2}{*}{ Total } \\
\hline & 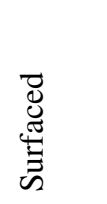 & 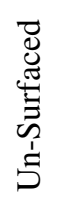 & 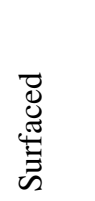 & 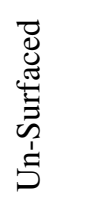 & 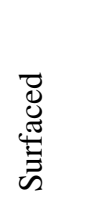 & 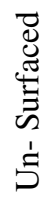 & 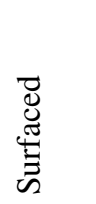 & 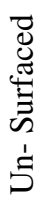 & \\
\hline khliganj & 63.37 & 1 & 8.25 & 20.6 & 31.5 & 0 & 17.6 & 0 & 142.32 \\
\hline Haldibari & 34 & 2 & 0 & 10.82 & 0 & 0 & 22.1 & 0 & 68.92 \\
\hline Mathabhanga I & 72.7 & 0 & 0 & 16.9 & 0 & 0 & 23.61 & 0 & 113.21 \\
\hline Mathabhanga II & 79 & 0 & 12.2 & 24.55 & 42 & 0 & 12.15 & 0 & 169.9 \\
\hline Sitalkuchi & 32 & 5 & 0 & 16.6 & 0 & 0 & 15.06 & 0 & 68.66 \\
\hline Cooch Behar I & 95.05 & 0 & 22.12 & 29.4 & 69 & 0 & 29.4 & 0 & 244.97 \\
\hline Cooch Behar II & 93.98 & 0 & 16 & 24.55 & 30 & 0 & 54.56 & 0 & 219.09 \\
\hline Tufanganj I & 78.74 & 0 & 14.26 & 22.28 & 26.5 & 0 & 15.59 & 0 & 157.37 \\
\hline Tufanganj II & 71.72 & 1 & 14.3 & 23.7 & 24.75 & 0 & 53.68 & 0 & 189.15 \\
\hline Dinhata I & 78.7 & 0 & 3 & 14.45 & & 0 & 24.66 & 0 & 120.81 \\
\hline Dinhata II & 79.74 & 0 & 16.42 & 26.65 & 35 & 0 & 21.34 & 0 & 179.15 \\
\hline Sitai & 14 & 6 & 2.8 & 10 & 4.5 & 0 & 4 & 0 & 41.3 \\
\hline
\end{tabular}

Source: District Statistical Hand Book, 2008 


\section{Methodology}

Topological map of 12 blocks of the study area Cooch Behar District were prepared. 127 centre or nodes from 12 blocks related to the structural analysis of existing road networks of Cooch Behar district were identified on the basis of following characteristics-

1. Urban centres

2. Administrative head quarters

3. Regional and local market centres

4. Centres for education

5. Location point of health centres

To describe the road network quantitatively and to compare the network of a block exactly with the other networks of different blocks following indicators have been analysed.

Table 1 Formula for Structural Analysis of Existing Road Networks

\begin{tabular}{|c|c|c|c|}
\hline S/ No. & Indices & Formula & Correlation with connectivity \\
\hline \multirow[t]{2}{*}{1} & \multirow[t]{2}{*}{ Road Density } & Road Length & \multirow{2}{*}{$\begin{array}{l}\text { Higher the density higher the } \\
\text { development }\end{array}$} \\
\hline & & $\overline{A r e a s q . K m}$ & \\
\hline 2 & Beta Index & $\beta=\frac{e}{-}$ & Higher value indicates more connectivity \\
\hline 3 & Alpha Index & $e-v+1$ & Higher value indicates more connectivity \\
\hline \multirow[t]{2}{*}{4} & Gamma Index & $\alpha=\frac{2 v-5}{e}$ & \multirow[t]{2}{*}{ Higher value indicates more connectivity } \\
\hline & & $y=\overline{3(v-2)}$ & \\
\hline 5 & Cyclomatic Number & $\mu=e-v+1$ & Higher value indicates more connectivity \\
\hline 6 & $\begin{array}{c}\text { Aggregate } \\
\text { Transportation } \\
\text { Score (ATS) }\end{array}$ & $A T S=\beta+\alpha+\gamma+\mu$ & $\begin{array}{l}\text { Higher value indicates more connectivity } \\
\text { and efficiency }\end{array}$ \\
\hline
\end{tabular}

\section{Result and Discussion}

Structural Analysis of Existing Road Networks of Cooch Behar District

Structure in transport geography refers to a system of arrangement consisting of a number of edges and vertices in a plain surface in terrestrial surface by making a nexus of spatial activities of people in order to get the connectivity.

\section{Road Density}

Density of road network indicates the length of road per unit of geographical area which discerns the degree of connectivity and accessibility of the road network system. The average density of the road network system of Cooch Behar district is $0.50 \mathrm{~km} / \mathrm{Sq}$. Km.

The district has been classified into three regions on the basis of road density. Three blocks namely Sitai (.25), Sitalkuchi (.26) and Mathabhanga I (.35) belong to the lower road density region. On the other hand, five blocks namely Dinhata I (.42) Haldibari (.44), Mekhliganj (.46), Tufanganj I (.49) and Mathabhanga II (.54) belong to the moderate road density region while only four blocks namely Cooch Behar II (.56), Cooch Behar I (.66) Tufanganj II (.71) and Dinhata II (.72) belong to high road density region (Table 3,4 ).

\section{Beta Index $(\boldsymbol{\beta})$}

One of the simplest measures of connectivity is beta index $(\beta)$ which can be found dividing the total number of arcs of a network by the total number of the nodes. Beta index ranges from 0.0 to network which consist just of nodes no arcs. If the value of beta index is greater than 1, the networks are well connected and higher values indicate higher the complexities of the networks. In the study area Cooch Behar district, out of 12 blocks Mathabhanga II and Dinhata I have the lowest beta index value i.e. 1.1. On the other hand, Tufanganj I has the highest beta index value i.e. 
1.93 enjoyed the most complex road network. The entire district has been divided into three regions on the basis of obtained beta values.

In the study area, there are only two blocks namely Tufanganj I (1.93) and Mekhliganj (1.9) have the most complex and well connected road networks. While three blocks namely, Dinhata II
(1.6), Sitai (1.4) and Cooch Behar I (1.38) have moderate well connected road network and rest even blocks namely, Mathabhanga I (1.36), Cooch Behar II (1.33), Tufanganj II (1.25), Haldibari (1.25), Sitalkuchi (1.23), Mathabhanga II (1.1), Dinhata I (1.1), have the lowest well connected road network (Table 5, 9).

Table 3 Inter Block Road Density of Cooch Behar District

\begin{tabular}{lrrr}
\hline \multicolumn{1}{c}{ Blocks } & Area in sq km & $\begin{array}{c}\text { Total Road } \\
\text { Length }(\mathrm{Km} .)\end{array}$ & $\begin{array}{c}\text { Road Density } \\
\text { Km/Sq. Km }\end{array}$ \\
\hline Mekhliganj & 305.95 & 142.32 & 0.465174048 \\
Haldibari & 153.83 & 68.92 & 0.448027043 \\
Mathabhanga I & 322.76 & 113.21 & 0.35075598 \\
Mathabhanga II & 309.99 & 169.9 & 0.548082196 \\
Sitalkuchi & 262.51 & 68.66 & 0.261551941 \\
Cooch Behar I & 369.46 & 244.97 & 0.663048774 \\
Cooch Behar II & 385.38 & 219.09 & 0.568503814 \\
Tufanganj I & 320.75 & 157.37 & 0.490631333 \\
Tufanganj II & 265.69 & 189.15 & 0.711919907 \\
Dinhata I & 284.22 & 120.81 & 0.425058054 \\
Dinhata II & 246.98 & 179.15 & 0.725362378 \\
Sitai & 160.82 & 41.3 & 0.256808855 \\
\hline
\end{tabular}

Source: District Statistical Hand Book 2008 and compiled by the Researcher

Table 4 Summery for Road Density

\begin{tabular}{|l|l|l|}
\hline Low Density & $.25-.40$ & Sitai (.25), Sitalkuchi (.26) and Mathabhanga I (.35) \\
\hline Moderate Density & $.40-.55$ & $\begin{array}{l}\text { Dinhata I (.42) Haldibari (.44), Mekhliganj (.46), Tufanganj I (.49) and } \\
\text { Mathabhanga II (.54) }\end{array}$ \\
\hline High Density & $.55-.72$ & $\begin{array}{l}\text { Cooch Behar II (.56), Cooch Behar I (.66) Tufanganj II (.71) and Dinhata } \\
\text { II (.72) }\end{array}$ \\
\hline
\end{tabular}

Table 5 Summery for Beta Index $(\boldsymbol{\beta})$

\begin{tabular}{|l|l|l|}
\hline Lower value & $1.1-1.37$ & $\begin{array}{l}\text { Haldibari, Mathabhanga I and II, Sitalkuchi, Cooch Behar II, } \\
\text { Tufanganj II and Dinhata I }\end{array}$ \\
\hline Moderate value & $1.37-1.64$ & Dinhata II, Sitai and Cooch Behar I \\
\hline Higher value & $1.64-1.93$ & Tufanganj I and Mekhliganj \\
\hline
\end{tabular}

\section{Alpha Index $(\alpha)$}

The alpha index is a ratio measure of the number of the actual circuits, to the maximum of in a given network. The range of the index is from a value of 0 for a minimally connected network to a value of 1 for a maximally connected one. The district has been divided into four regions on the basis of obtained alpha values.

Tables 6 and 9 indicate that Haldibari (0), Mathabhanga II (0) and Dinhata I (0) have 
minimally connected road network having the alpha index value 0 . Six blocks namely, Tufanganj II (.09), Sitalkuchi (.13) and Cooch Behar I (.19), Sitai (.2), Mathabhanga I (.25) and Cooch Behar II (.27) belong to the lower alpha index region having lower connected road network. While Dinhata II (.38) belongs to the moderate alpha index region having moderate connected road network. On the other hand only two blocks namely, Tufanganj I (0.67) and Mekhliganj (0.53) belong to comparatively higher connected road network.

\section{Gamma Index $(y)$}

Connectivity as measured by the Gamma index is expressed in terms of a graph theoretic range, that varies from a set of nodes having no interconnection of one centre to a set of nodes in which every node has an edge connecting it to every other node in the graph (Shing, 2003). Simply Gamma index is a ratio between the observed number of edges and vertices of a given transportation network. The numerical range for the Gamma Index is between 0 and 1. Higher the value indicates higher the development of network.

Tables 7, 9 indicate that three blocks viz. Mekhliganj (.79), Sitai (.78) and Tufanganj I (.75) belong to the higher gamma index region. On the other hand only one block namely Dinhata II (.67) belongs to the moderate beta index region. Rest eight blocks namely Dinhata I (.46), Mathabhanga I (.46), Sitalkuchi (.48), Cooch Behar II (.51), Cooch Behar I (.55), Haldibari (.56), Mathabhanga I (.56) and Tufanganj II (.56) belong to lower gamma index region.

\section{Cyclomatic Number $(\boldsymbol{\mu})$}

Cyclomatic number is based upon the condition that as soon as a connected network has enough arcs or links to for a tree, then additional arcs will results in the formation of circuits. The cylomatic number 0 indicates a tree type graph, whereas the graph closer and closer to the completely connected state, the cyclomatic number increases. A disadvantage of this method is that networks with very different forms may have the same cyclomatic number (Waugh, 1995).

Tables 8 and 9 indicate that the cylomatic number 0 of Mathabhanga II block indicates a tree type graph while block namely Tufanganj I (12), having the highest cylomatic number represents its more closeness and more connected state of road network. On the other hand only two blocks namely Dinhata II (5) and Mekhliganj (8) belong to the moderate cyclomatic index region having moderate value. Rest eight blocks namely Sitai (1), Dinhata I (1), Tufanganj II (1), Haldibari (1) Sitalkuchi (2), Mathabhanga I (3), Cooch Behar II (4) and Cooch Behar I (4) have low value of cylomatic number and belong to the low cyclomatic number region.

\section{A.T.S (Aggregate Transportation Score)}

It is clear that the blocks namely Mathabhanga II (1.56), Haldibari (1.81), Tufanganj II (2.9), Dinhata I (2.56), Sitai (3.38), Sitalkuchi (3.84), Mathabhanga I (5.17), Cooch Behar II (6.11), and Cooch Behar I (6.12) have almost equal and lower level of connectivity ranging from 1.56 to 6.15. Again, the block like Dinhata II (7.6) has slightly better level of connectivity if compared with the previous category. Moreover, two blocks i.e. Mekhliganj (11.22) and Tufanganj I (15.35) have higher A.T.S value which results higher degree of connectivity (Table 9, 10). Therefore the overall picture of connectivity in the region under study is more or less uniform with little regional variations.

Table 6 Summery for Alpha Index $(\boldsymbol{\alpha})$

\begin{tabular}{|l|l|l|}
\hline Lowest value & 0 & Haldibari (0), Mathabhanga II (0) and Dinhata I (0) \\
\hline Lower value & $0.9-0.28$ & $\begin{array}{l}\text { Tufanganj II (.09), Sitalkuchi (.13) and Cooch Behar I (.19), Sitai (.2), } \\
\text { Mathabhanga I (.25) and Cooch Behar II (.27) }\end{array}$ \\
\hline Moderate value & $0.28-0.47$ & Dinhata II (.33) \\
\hline Higher value & $0.47-0.66$ & Tufanganj I (0.67) and Mekhliganj (0.53) \\
\hline
\end{tabular}


Table 7 Summery for Gamma Index $(r)$

\begin{tabular}{|l|l|l|}
\hline Lower value & $.46-.57$ & $\begin{array}{l}\text { Dinhata I (.46), Mathabhanga I (.46), Sitalkuchi (.48), Cooch Behar II } \\
(.51), \text { Cooch Behar I (.55), Haldibari (.56), Mathabhanga I (.56) and } \\
\text { Tufanganj II (.56) }\end{array}$ \\
\hline Moderate value & $.57-.68$ & Dinhata II, \\
\hline Higher value & $.68-.79$ & Mekhliganj (.79), Sitai (.78) and Tufanganj I (.75) \\
\hline
\end{tabular}

Table 8 Summery for Cyclomatic Number $(\boldsymbol{\mu})$

\begin{tabular}{|l|l|l|}
\hline Lowest value & 0 & Mathabhanga II \\
\hline Lower value & $1-4.66$ & $\begin{array}{l}\text { Sitai (1), Dinhata I (1), Tufanganj II (1), Haldibari (1) Sitalkuchi (2), } \\
\text { Mathabhanga I (3), Cooch Behar II (4) and Cooch Behar I (4) }\end{array}$ \\
\hline Moderate value & $4.66-8.32$ & Dinhata II (5) and Mekhliganj (8) \\
\hline Higher value & $8.32-12$ & Tufanganj I (12) \\
\hline
\end{tabular}

Table 9 Block Wise Composite Score of Road Transportation in Cooch Behar district

\begin{tabular}{llllllll}
\hline Blocks & Node & Edge & $\begin{array}{l}\text { Beta } \\
\text { Index }\end{array}$ & $\begin{array}{l}\text { Alpha } \\
\text { Index }\end{array}$ & $\begin{array}{l}\text { Gamma } \\
\text { Index }\end{array}$ & $\begin{array}{l}\text { Cyclomatic } \\
\text { Number }\end{array}$ & A.T.S \\
\hline Mekhliganj & 10 & 19 & 1.9 & 0.53 & 0.79 & 8 & 11.22 \\
Mekhliganj & 8 & 10 & 1.25 & 0 & 0.56 & 1 & 2.81 \\
Haldibari & 11 & 15 & 1.36 & 0.25 & 0.56 & 3 & 5.17 \\
Mathabhanga I & 10 & 11 & 1.1 & 0 & 0.46 & 0 & 1.56 \\
Mathabhanga II & 13 & 16 & 1.23 & 0.13 & 0.48 & 2 & 3.84 \\
Sitalkuchi & 13 & 18 & 1.38 & 0.19 & 0.55 & 4 & 6.12 \\
Cooch Behar I & 15 & 20 & 1.33 & 0.27 & 0.51 & 4 & 12.35 \\
Cooch Behar II & 14 & 27 & 1.93 & 0.67 & 0.75 & 12 & 2.9 \\
Tufanganj I & 8 & 10 & 1.25 & 0.09 & 0.56 & 1 & 2.56 \\
Tufanganj II & 10 & 16 & 1.1 & 0 & 0.46 & 1 & 7.6 \\
Dinhata I & 10 & 11 & 1.6 & 0.33 & 0.67 & 5 & 3.38 \\
Dinhata II & 5 & 7 & 1.4 & 0.2 & 0.78 & 1 & \\
\hline
\end{tabular}

Table 10 Summary for A.T.S

\begin{tabular}{|l|l|l|}
\hline Lower value & $1.56-6.15$ & $\begin{array}{l}\text { Mathabhanga II (1.56), Haldibari (1.81), Tufanganj II (2.9), Dinhata I } \\
(2.56), \text { Sitai (3.38), Sitalkuchi (3.84), Mathabhanga I (5.17), Cooch } \\
\text { Behar II (6.11), and Cooch Behar I (6.12) }\end{array}$ \\
\hline Moderate value & $6.15-10.74$ & Dinhata II (7.6) \\
\hline Higher value & $10.74-15.35$ & Mekhliganj (11.22) and Tufanganj I (15.35) \\
\hline
\end{tabular}

\section{Major Findings}

1. The district has $0.5 \mathrm{~km} / \mathrm{Sq}$. Km road density, which is not satisfactory in position. Inter block variation of road density is very low.

2. There is a little variation among the blocks in terms of Beta Index and Gamma Index.

3. Three blocks namely Haldibari, Mathabhanga II and Dinhata I have minimally connected road networks in spite of its moderate density of road networks.

4. Mathabhanga II block has tree type of graph which represents the least close road networks. Inter block variation of cyclomatic number is very high.

5. Tufanganj I and Mekhliganj have higher close and connected state of road networks in spite of its moderate road density.

6. Cooch Behar I and II blocks have lower development in terms of road connectivity 
and efficiency in spite of their central location.

7. Nine blocks namely, Mathabhanga II, Haldibari, Tufanganj II, Dinhata I, Sitai, Sitalkuchi, Mathabhanga I, Cooch Behar II, and Cooch Behar I have lower development of transportation in terms of connectivity and have the least efficient road network in the district.

\section{Conclusion}

The study reveals that in 2008, no blocks of Cooch Behar district had road density more than $1 \mathrm{~km}$ per square $\mathrm{km}$ and most of the blocks characterised by minimum efficiency of road network in terms of connectivity. Therefore, it is clear and evident from above discussion that the study area has been experiencing lack of spatial efficiency due to shortage road length. The consequence of which is very uneven spatial development when only a few parts of the study area is equated with well road network. As movements of people, goods and services are highly associated with efficiency of places, naturally the blocks of the study area deprived of attaining this facility. Thus, nature of developmental efficiency is also poorer in the study area experiencing a large scale deprivation from every aspect of developmental issues in spite of its immense potentiality from different perspectives like agriculture, tourism, agro based industries. These local facilities cannot be utilized properly without radical improvement of existing transportation (Cooley, 1894). Physical constraints like flood and monsoonal rainfall hinder transport development but at the same time it is also true that lack of transparency in between different Governmental organizations is another important factor for this. The progress of transportation is also necessarily dependent upon the consolidation of political power (Cooley, 1894). Number of roads in all blocks of the district should be increased to achieve the better connectivity and accessibility as improvement of transportation, including rural roads, is said to form the most valuable aspect of rural development (Hodder, 1971; William, 1978). Efficiency of road network should be enriched in all aspects for proper utilisation of available resources. Not only the quantity but also the quality of the road network should be developed to achieve enough efficiency. Therefore, due attention should be paid by making required number of road to enhance mobility and efficiency in the district, otherwise transport optimacy and its related development never be attained.

\section{References}

Badigar, G. S., Badigar, K. R. (2003). Impact of Transportation Development on Industrialisation in Goa. In B.C. Vaidya (Ed.), Geography of Transport development in India (pp. 250-272). New Delhi: Concept Publishing Company

Cooley, C. H., (1894). The Theory of Transportation. The American Economic Association, 9(3), 13-148 retrieve from http://www.jstor.org/stable/2485676

Gautam, P.S. (1992). Transport Geography of India. New Delhi: Mittal Publication. pp. 1-3

Hodder, B. W. (1971). Economic development reference to roads and road transport. Dar-es salamSalam: University College.

Kansky, K. J. (1963). Structure of Transportation Networks Networks: Relation between Netwok Geometry and Regional Charecteristics, Universirty of Chicago, Department of Geography, Research Papers No.84

Saxena, H. M. (2010). Transport Geography. New Delhi: Rawat Publication.

Simon, D. (1996). Transport and development in the third world. Routeledge. NY:

Taaffe, E. J., Gautheir, H. L. (1973). Geography of Transportation. Englewood Cliffs: Prentice Hall Umoren, V., Ikurekong, E. E., Emmanuel, A \& Udida, A. A. (2009). Development Envelopment of Road Infrastructure as a Tool of Transforming Ibiono Ibom Local Government Area. Global Journal of Social Sciences, 8(2), 53-59.

Waugh, D. (1995). Geography- An Integrated Approach. Melbourne: Thomas Nelson and sons Ltd. 